\title{
HUBUNGAN MINAT BELAJAR IPA SISWA KELAS V SD NEGERI 2 PELEMKEREP TERHADAP HASIL BELAJAR SELAMA PEMBELAJARAN DARING
}

\author{
Dicky Ahmad Nor Sidiq ${ }^{1, *}$, Fina Fakhriyah ${ }^{2)} \&$ Siti Masfuah $^{3)}$ \\ 1), 2), 3) Universitas Muria Kudus, Kota Kudus, Indonesia \\ E-mail: dickyahmad2017@gmail.com
}

\begin{tabular}{|c|c|}
\hline ARTICLE INFO & ABSTRACT \\
\hline $\begin{array}{l}\text { Article history } \\
\text { Received: August 18, } 2020 \\
\text { Revised: August 22, } 2020 \\
\text { Accepted: August 24, } 2020 \\
\text { Keywords: } \\
\text { online learning, interest in } \\
\text { learning, and learning } \\
\text { outcomes }\end{array}$ & $\begin{array}{l}\text { The purpose of this study was to analyze the students' interest in learning } \\
\text { science class VSD Negeri } 2 \text { Pelemkerep during online learning and to analyze } \\
\text { the relationship between interest in learning science and learning outcomes } \\
\text { for students at SD Negeri } 2 \text { Pelemkerep during online learning. This study } \\
\text { uses a quantitative approach to the type of correlation research. Correlation } \\
\text { research is a study conducted to find the level of relationship between } \\
\text { variables and to find out how big the relationship between each variable is } \\
\text { used. This research was conducted in class V SD Negeri } 2 \text { Pelemkerep Jepara. } \\
\text { The independent variable in this study is the interest in learning science, while } \\
\text { the dependent variable is the result of learning science. The data analysis } \\
\text { technique used is the product moment correlation test and one sample t test. } \\
\text { The results of this study indicate that (1) there is a relationship between } \\
\text { interest in learning science and learning outcomes of students at SD Negeri } 2 \\
\text { Pelemkerep during online learning with a correlation coefficient value of } \\
0.905 \text { in the very strong category and (2) the average interest in learning } \\
\text { science for students at SD Negeri } 2 \text { Pelemkerep during online learning }>50 \% \\
\text { with an average value of the questionnaire on learning interest of } 86.04 \text { and } \\
\text { an average value of learning outcomes in science learning of } 83.78 . \text { Based on } \\
\text { the results of the calculation, the average percentage of the answers to the } \\
\text { questionnaire on the students' interest in learning science as a whole was } \\
54.36 \% \text {, meaning that most students had an interest in learning science. }\end{array}$ \\
\hline
\end{tabular}

\section{A. PENDAHULUAN}

Perkembangan teknologi informasi dan komunikasi memberikan dampak yang signifikan bagi kehidupan masyarakat, salah satunya dalam bidang pendidikan. Dengan adanya pemanfaatan teknologi informasi bagi dunia pendidikan, maka dapat menghasilkan sumber daya manusia berkualitas dengan melakukan perbaikan kondisi pendidikan (Husaini, 2014). Banyaknya sumber belajar yang bersumber dari internet memungkinkan masyarakat dapat mengaksesnya melalui smartphone atau gadget sehingga memungkinkan untuk melakukan pembelajaran secara online.

Indonesia tengah dihadapkan dengan sebuah fenomena pandemi Covid-19 dengan kasus penyebaran virus Corona atau Covid-19 yang terus meningkat setiap harinya. Dampak pandemi Covid-19 kini mulai merabah dunia pendidikan, Presiden dan Mendikbud setelah 
melakukan rapat terbatas melihat perkembangan penyebaran Covid-19, pada tanggal 24 Maret Mendikbud mengeluarkan SE Nomor 4 Tahun 2020 tentang pelaksanaan Kebijakan Pendidikan dalam Masa Darurat Penyebaran Corona Virus Disease (Covid-19). Surat Edaran (SE) tersebut ditunjukan kepada para Gubenur, dan Bupati/ Walikota di seluruh Indonesia dengan tembusan kepada seluruh Kepala Dinas Pendidikan Provinsi, seluruh Kepala Dinas Kabupaten/ Walikota dan Kepala seluruh Satuan Pendidikan. Surat Edaran (SE) tersebut berisi beberapa hal mengenai pendidikan, salah satunya adalah proses belajar dari rumah melalui pembelajran daring/jarak jauh. Dengan adanya pembelajaran daring, kegiatan pembelajaran pada sekolah maupun kampus yang biasanya dilakukan secara konvensional, kini semua harus dilakukan dengan pembelajaran daring guna untuk memutus mata rantai penyebaran virus corona. Pembelajaran daring merupakan pemanfaatan jaringan internet dalam proses pembelajaran (Isman, dalam Sobron, dkk., 2019).

Pembelajaran daring diselengarakan di sekolah dasar dimana peserta didik dan guru berada pada lokasi yang terpisah sehingga memanfaatan jaringan internet dalam proses pembelajarannya. Pembelajaran adalah segala sesuatu yang dapat membawa informasi dan pengetahuan dalam interaksi yang berlangsung antara pendidik dan peserta didik (Azhar, 2011). Pihak sekolah juga merespon positif kebijakan pembelajaran daring tersebut sebagai upaya yang dilakukan untuk menghambat laju penyebaran Covid-19 dengan langsung menerapkan pembelajaran online di semua mata pelajaran. Ilmu Pengetahuan Alam (IPA) adalah salah satu pembelajaran pokok yang harus dipelajari siswa disekolah.

Secara umum, IPA adalah ilmu tentang fenomena alam semesta. Sebagaimana dikemukakan oleh Widodo (dalam Putri, dkk., 2018) IPA atau sains merupakan salah satu cabang ilmu yang fokus kajiannya adalah alam dan proses proses yang ada di dalamnya. IPA tidak hanya berupa kumpulan pengetahuan seperti fakta-fakta, konsep-konsep, atau prinsipprinsip, tetapi juga merupakan suatu proses pembelajaran yang memberikan pengalaman langsung kepada siswa untuk memahami alam sekitar secara ilmiah (Kallesta \& Erfan, 2017). Dengan adanya pembelajaran daring yang diterapkan pada pembelajaran IPA, diharapkan minat belajar IPA siswa tidak terpengaruh. Handayani (2016) menjelaskan bahwa minat belajar adalah kecenderungan individu untuk memiliki rasa senang, dorongan melakukan aktivitas terhadap kegiatan belajar yang dilakukan melalui latihan-latihan ataupun pengalaman. Minat belajar IPA dapat diukur menggunakan indikator minat belajar yang dikemukakan Safari (dalam Ricardo \& Meilani, 2017) mengemukakan ada beberapa indikator yang digunakan untuk mengukur minat belajar siswa untuk belajar, yaitu perhatian, ketertarikan, rasa senang, dan keterlibatan. 
Setiap proses pembelajaran tentunya diharapakan peserta didik memperoleh hasil belajar yang baik. Sebagaimana yang menjadi standar baik atau tidaknya hasil belajar atas dasar KKM yang telah ditetapkan sebegai patokan keberhasilan proses pembelajaran. Hasil belajar siswa menunjukan kemampuan dan kualitas siswa sebagai dampak dari proses pembelajaran yang dilaluinya. Nurhasanah \& Sobandi (2016) menjelaskan bahwa hasil belajar siswa dapat ditingkatkan melalui peningkatan minat belajar siswa. Artinya semakin baik minat belajar siswa akan berdampak hasil belajar siswa yang semakin baik.

Penerapan pembelajaran daring di sekolah dasar, merupakan hal yang baru sehingga siswa dan guru mengalami beberapa kendala. Berdasarkan wawancara dengan siswa kelas IV SD Negeri 2 Pelemkerep diketahui bahwa terdapat beberapa kendala yang dihadapi selama pembelajaran daring diantaranya adalah sulit memahami materi yang disampaikan guru secara online dan paketan internet serta sinyal internet yang kurang bagus. Sedangkan wawancara mengenai kendala pembelajaran daring dengan guru kelas IV yang menjelaskan banyak siswa yang mengeluh saat mengunduh/menonton materi yang berupa video karena paketan internet yang terbatas serta sinyal yang kurang bagus. Kemudian karena pembelajaran dilakukan setiap hari di rumah siswa lama kelamaan menjadi bosan, dia juga ingin bermain bersama temannya karena teman sebayanya juga dapat membangkitkan minat belajar siswa. Siswa juga hanya beberapa yang berani bertanya kalau ada kesulitan. Selanjutnya wawancara tentang kendala pembelajaran daring dengan orang tua siswa yang bernama Juli Puji Astuti pada 20 Juni 2020 menjelaskan bahwa pembelajaran daring masih baru di sekolah dasar sehingga belum efektif bagi dan anak cenderung meminta bantuan dalam mengerjakan tugas yang diberikan oleh guru. Dengan adanya kendala-kendala yang dialami selama pembelajaran daring maka minat belajar siswa juga ikut terpengaruh.

\section{B. METODE PENELITIAN}

Penelitian ini dilaksanakan di kelas V SD Negeri 2 Pelemkerep pada bulan Juli sampai Agustus 2020. Populasi dalam penelitian ini adalah seluruh siswa SD Negeri 2 Pelemkerep dengan jumlah 222 siswa. Pengambilan sampel dilakukan dengan cara Purposive Sampling. Sampel yang diguanakan adalah siswa V SD Negeri 2 Pelemkerep karena minat belajar IPA siswa kurang baik selama pembelajaran daring.

Penelitian ini dilakukan menggunakan pendekatan kuantitatif. Jenis penelitian yang dipilih yaitu penelitian korelasi. Variabel yang digunakan dalam penelitian ini, yaitu minat belajar IPA (X) sebagai variabel bebas (independen) dan Hasil belajar IPA (Y) sebagai variabel terikat (dependen). Jenis data yang dikumpulkan dalam penelitian ini berdasarkan pada 
variabel penelitian, yakni data tentang variabel bebas $(\mathrm{X})$ yaitu minat belajar, dan variabel terikat (Y) yaitu hasil belajar yang dikumpulkan dengan angket minat belajar IPA dan nilai hasil ulangan IPA semester genap tahun 2019/2020. Pengumpulan data pada penelitian ini menggunakan wawancara, angket, tes, dan dokumentasi. Wawancara berisi daftar pertanyaan yang ditanyakan pada guru, siswa, dan orang tua siswa kelas V SD Negeri 2 Pelemkerep. Angket digunakan untuk mengetahui bagaimana minat belajar IPA siswa selama pembelajaran daring, angket berisi 30 soal pernyataan yang terdiri atas 15 pernyataan positif dan 15 pernyataan negatif. Kemudian tes digunakan untuk mengukur hasil belajar IPA selama pembalajran daring, nilai hasil belajar yang diambil adalah nilai ulangan IPA pada tema 9 Kayanya Negeriku. Analisis data yang digunakan yaitu uji korelasi dan uji t satu sampel. Uji korelasi digunakan untuk mengetahui hubungan minat belajar dan hasil belajar siswa. Uji t satu sampel digunakan untuk mengetahui rata-rata minat belajar IPA selama pembelajaran daring.

\section{HASIL DAN PEMBAHASAN}

Hasil penelitian ini meliputi: (1) hubungan minat belajar IPA terhadap hasil belajar selama pembelajaran daring dan (2) rata-rata minat belajar IPA siswa SD Negeri 2 Pelemkerep selama pembelajaran daring.

\section{Hubungan Minat Belajar IPA Terhadap Hasil Belajar Selama Pembelajaran Daring}

Analisis hubungan minat belajar IPA terhadap hasil belajar menggunakan uji korelasi product moment dari Pearson. Hasil analisis dapat dilihat pada Tabel 1.

Tabel 1. Hasil analisis uji korelasi hubungan minat belajar ipa terhadap hasil belajar IPA

\begin{tabular}{ccccc}
\hline Data & $\begin{array}{c}\text { Koefisien } \\
\text { Korelasi }\end{array}$ & Kategori & $\begin{array}{c}\text { Sig (2- } \\
\text { tailed) }\end{array}$ & Kesimpulan \\
\hline $\begin{array}{c}\text { Nilai angket minat terhadap } \\
\text { nilai hasil belajar IPA }\end{array}$ & 0,905 & $\begin{array}{c}\text { Sangat } \\
\text { Kuat }\end{array}$ & 0,000 & $\begin{array}{c}\text { Terdapat hubungan minat } \\
\text { dengan hasil belajar }\end{array}$ \\
\hline
\end{tabular}

Berdasarkan Tabel 1 diketahui hasil uji korelasi variabel minat belajar dengan variabel hasil belajar IPA siswa sebesar 0,905. Hasil hitung tersebut menunjukkan angka yang positif, nilai koefisien korelasi (r) pada uji tersebut termasuk dalam kategori sangat kuat berdasarkan pedoman interpretasi koefisien korelasi. Diperoleh bahwa nilai signifikansi sebesar 0,000 kemudian dibandingan dengan taraf signifikan $\alpha=0,05$. Diperoleh bahwa nilai signifikansi $<$ taraf signifikansi $\left(\frac{1}{2} \alpha\right)$ yaitu $0,000<0,025$, maka $\mathrm{H}_{\mathrm{o}}$ ditolak.

Dari hasil perhitungan di atas, angka korelasi antara variabel X (minat belajar IPA) dan variabel Y (hasil belajar IPA) bertanda positif (korelasi yang berjalan searah). Kemudian dengan memperhatikan besarnya nilai koefisien $\left(R_{x y}\right)$ sebesar 0,905 berarti korelasi variabel X 
terhadap variabel Y termasuk dalam kategori sangat kuat. Dengan demikian dapat disimpulkan bahwa korelasi yang sangat kuat dan positif antara variabel $\mathrm{X}$ dan variabel $\mathrm{Y}$ berarti minat belajar merupakan salah satu faktor penting dalam meningkatkan hasil belajar IPA siswa kelas V SD Negeri 2 Pelemkerep.

Penelitian ini menunjukkan nilai signifikansi sebesar 0,000. Pada taraf signifikansi 5\%, menunjukkan bahwa rhitung < rtabel $(0,00<0,176)$ yang berarti ada hubungan yang signifikan antara variabel minat belajar IPA (X) dengan hasil belajar IPA (Y). Semakin tinggi minat belajar siswa maka makin tinggi pula hasil belajar yang didapatkan, sebaliknya semakin rendah minat belajar siswa maka semakin rendah pula hasil belajar yang didapatkan oleh siswa.

Hasil uji hipotesis menunjukkan bahwa $\mathrm{H}_{\mathrm{o}}$ ditolak dan $\mathrm{H}_{\mathrm{a}}$ diterima. Penelitian dengan uji hipotesis antara variabel minat belajar IPA (X) dengan hasil belajar IPA (Y) SD Negeri 2 Pelemkerep terdapat hubungan korelasi yang sangat kuat, positif, dan signifikan. Sehingga dapat disimpulkan bahwa terdapat hubungan minat belajar IPA dengan hasil belajar IPA siswa SD Negeri 2 Pelemkerep selama pembelajaran daring.

Penelitian ini diperkuat dengan penelitian Sari, dkk. (2019) menyatakan bahwa berdasrkan statistik uji-t di peroleh $t_{\text {hitung }}=4,79$ dan $t_{\text {tabel }}=2,022$, $t_{\text {hitung }}>t_{\text {tabel }}$ pada taraf nyata 0.05 dengan diperoleh hasil koefisien korelasi $r_{x y}=0,73$ dan koefisien determinan sebesar $53,29 \%$. Hal ini menunjukkan bahwa Ho ditolak dan Ha diterima. Ini berarti terdapat hubungan antara minat dengan hasil belajar peserta didik SDN 25 Jati Tanah Tinggi.

Penelitian ini juga diperkuat penelitian Budiwibowo (2016) menyatakan hasil pengujian hipotesis, terdapat hubungan yang signifikan antara minat belajar siswa pada mata pelajaran IPS dengan hasil belajar siswa. Hal ini diperoleh rhitung sebesar 0,638 $\geq$ rtabel 0,195 dengan signifikans 0,05 atau taraf kepercayaan $95 \%$, pada $\mathrm{n}=122$ menunjukan bahwa hipotesis alternative yang menyatakan ada hubungan antara minat belajar dan hasil belajar siswa untuk mata pelajaran IPS di SMP Negeri 14 kota Madiun diterima.

Penelitian lain yang juga memperkuat penelitian ini adalah penelitian Berutu \& Tambunan (2018) menyatakan bahwa hasil penelitian dan pengujian analisis korelasi menunjukkan: (1) Terdapat pengaruh minat terhadap hasil belajar biologi siswa SMA ( $\mathrm{r}=$ 0,451; $\mathrm{P}=0,000)$. (2) Terdapat pengaruh kebiasaan belajar terhadap hasil belajar biologi siswa SMA $(r=0,045 ; P=0,000)$. 


\section{Rata-rata Minat Belajar IPA Siswa SD Negeri 2 Pelemkerep Selama Pembelajaran Daring}

Analisis rata-rata minat belajar IPA selama pembelajaran daring menggunakan uji t satu sampel. Hasil analisis dapat dilihat pada Tabel 2.

Tabel 2. Hasil analisis uji t satu sampel rata-rata minat belajar IPA

\begin{tabular}{ccc}
\hline Data & Sig (2-tailed) & Kesimpulan \\
\hline Nilai angket minat belajar IPA & 0,000 & Rata-rata minat belajar IPA $>50 \%$ \\
\hline
\end{tabular}

Hasil analisis uji t satu sampel pada nilai angket minat belajar IPA menunjukan bahwa nilai signifikansi sebesar 0,000. Berdasarkan hasil analisis nilai angket nilai signifikansi kurang dari nilai $\alpha=0,05$. Karena $0,000<0,05$ maka $\mathrm{H}_{\mathrm{o}}$ ditolak. Sehingga dapat disimpulkan bahwa rata-rata minat belajar IPA siswa SD Negeri 2 Pelemkerep selama pembelajaran daring $>50 \%$.

Rata-rata nilai hasil belajar IPA siswa kelas V SD Negeri 2 Pelemkerep setelah dilaksanakan pembelajaran daring adalah 83,78. Kemudian hasil nilai angket minat belajar memiliki rata-rata nilai minat belajar IPA siswa kelas V SD sebesar 86,04. Sehingga disimpulkan minat belajar yang baik selama memiliki pengaruh terhadap hasil belajar siswa. Penelitian ini diperkuat dengan penelitian Pengestu, dkk. (2015) yang menyatakan minat belajar mempunyai pengaruh yang positif bagi hasil belajar matematika siswa SMA Negeri 1 Uluwoi. Hasil penelitian lain yang juga mendukung penelitian penelitian ini adalah hasil penelitian Siagian (2015) menyatakan bahwa 1. Adanya pengaruh positif minat dan kebiasaan belajar siswa secara bersama-sama terhadap prestasi belajar matematika, 2. Ada pengaruh minat belajar siswa terhadap prestasi belajar matematika, 3. Ada pengaruh kebiasaan belajar siswa terhadap prestasi belajar matematika.

Kemudian berdasarkan hasil perhitungan, diperoleh persentase rata-rata jawaban siswa secara keseluruhan sebesar 54,36\%. Hal ini menunjukan bahwa, persentase rata-rata minat belajar IPA siswa sebesar 54,36 \%. Artinya, sebagian besar siswa memiliki minat belajar IPA. Meskipun demikian, minat belajar IPA siswa masih perlu di tingkatkan.

\section{SIMPULAN}

Berdasarkan penelitian yang telah dilakukan dapat disimpulkan bahwa terdapat hubungan minat belajar IPA dengan hasil belajar IPA siswa SD Negeri 2 Pelemkerep selama pembelajaran daring dengan nilai koefisien korelasi sebesar 0,905 pada kategori sangat kuat. Rata-rata minat belajar IPA siswa SD Negeri 2 Pelemkerep selama pembelajaran daring lebih dari 50\% dengan hasil rata-rata nilai angket minat belajar sebesar 86,04 dan rata-rata nilai hasil 
belajar IPA sebesar 83,78. Berdasarkan hasil perhitungan, diperoleh persentase rata-rata jawaban angket minat belajar IPA siswa secara keseluruhan sebesar 54,36 \% artinya, sebagian besar siswa memiliki minat belajar IPA.

\section{DAFTAR PUSTAKA}

Arikunto, Suharsimi. 2013. Prosedur Penilaian Suatu Pendekatan Praktik. Jakarta: Rineka Cipta.

Arsyad, Azhar. (2011). Media Pembelajaran. Jakarta: Rajawali Pers.

Berutu, Muhammad Hasyim Ansari \& Tambunan, Muhammad Iqbal H. 2018. Pengaruh Minat dan Kabiasaan Belajar terhadap Hasil Belajar Biologi Siswa SMA Se-Kota Stabat. Jurnal Biolokus, 1(2), 109-116.

Budiwibowo, Satrijo. 2016. Hubungan Minat Belajar Siswa dengan Hasil Belajar IPS di SMP Negeri 14 Kota Madiun. Jurnal Studi Sosial, 1(1), 60-68.

Handayani, Santy. 2016. Pengaruh Perhatian Orangtua dan Minat Belajar Matematika terhadap Prestasi Belajar Matematika Siswa. Jurnal Formatif, 6(2): 141-148.

Husaini, H. 2014. Pemanfaat Teknologi Informasi dalam Bidang Pendidikan (E-education). Jurnal Miktrotik, 2(1), 18-23.

Kallesta, K. S., \& Erfan, M. (2017). Analisis Faktor Penyebab Kesulitan Belajar IPA Fisika pada Materi Bunyi. Jurnal Pendidikan Fisika, 1. https://doi.org/10.31227/osf.io/dwh5e

Kementerian Pendidikan dan Kebudayaan. 2017. Energi di Sekitarku. Jakarta: Kemendikbud.

Nushasanah, Siti \& Sobandi, A. 2016. Minat Belajar sebagai Determinan Hasil Belajar Siswa. Jurnal Pendidikan Manajemen Perkantoran, 1(1), 128-135.

Pangestu, Dwi Agung, Samparadja, Hafiludin, \& Tiya, Kadir. 2015. Pengaruh Minat Terhadap Hasil Belajar Matematika Siswa SMA Negeri 1 Uluiwoi Kabupaten Kolaka Timur. Jurnal Penelitian Pendidikan Matematika, 1(2), 17-26.

Putri, Ghina Fitriadi., Yasbiati, \& Pranata, Oyon Haki. 2018. Pengaruh Media Pop Up Card Terhadap Hasil Belajar Siswa pada Materi Penggolongan Hewan Berdasarkan Jenis Makanannya. Jurnal Ilmiah, 5(1), 174-183.

Ricardo \& Meilani, Rini Intansari. 2017. Impak Minat dan Motivasi Belajar Terhadap Hasil Belajar Siswa. Jurnal Pendidikan Manajemen Perkantoran, 2(2), 188-201.

Sari, Fitria Kumala., Rakimahwati, \& Fitria, Yanti. 2019. Hubungan Minat dengan Hasil Belajar Peserta didik pada Pembelajaran Matematika kelas VI SDN 25 jati Tanah Tinggi. Jurnal Basicedu, 3(2), 397-405. 
Sidiq, dkk. (2020). Hubungan Minat Belajar...

Siagian, Roida Eva Flora. 2015. Pengaruh Minat dan Kebiasaan Belajar Siswa terhadap Prestasi Belajar Matematika. Jurnal Ilmiah Pendidikan MIPA, 2(2), 122-131.

Sobron, A. N., Bayu., Rani \& Meidawati. 2019. Pengaruh Daring Learning terhadap Hasil Belajar IPA Siswa Sekolah Dasar. ISBN, 978-602-99975-3-8.

Sugiyono. 2016. Metode Penelitian Pendidikan. Bandung: Alfabeta. 